\title{
PERILAKU CYBERBULLYING PADA REMAJA DAN KAITANNYA DENGAN KONTROL DIRI DAN KOMUNIKASI ORANG TUA
}

\author{
Zahro Malihah, Alfiasari*) \\ Departemen IImu Keluarga dan Konsumen, Fakultas Ekologi Manusia, Institut Pertanian Bogor, \\ Bogor 16680, Indonesia
}

*) Email: alfiasari@apps.ipb.ac.id

\begin{abstract}
Abstrak
Peningkatan penggunaan teknologi internet pada anak-anak dan remaja memperbesar resiko terjadinya fenomena cyberbullying. Oleh karenanya, perlu dilakukan kajian untuk menganalisis lebih jauh tentang fenomena cyberbullying di Indonesia dikaitkan dengan faktor penyebabnya sehingga dapat dilakukan upaya pencegahan sedini mungkin. Penelitian ini bertujuan untuk menganalisis hubungan karakteristik orang tua dan remaja, komunikasi orang tua-remaja. serta kontrol diri terhadap perilaku cyberbullying remaja. Penelitian ini menggunakan desain cross sectional study. Penelitian ini dilaksanakan di salah satu SMP di Kota Bogor. Contoh pada penelitian ini berjumlah 81 remaja yang dipilih dengan menggunakan convenience sampling. Data diambil melalui self-administered dengan melakukan pengukuran pada persepsi remaja terhadap komunikasi orang tuaremaja serta pengukuran kontrol diri dan perilaku cyberbullying remaja. Hasil penelitian menunjukkan ratarata $\pm S D$ indeks $(0-100)$ untuk variabel komunikasi orang tua-remaja adalah $67,29 \pm 12,32$; kontrol diri remaja adalah 58,96 $\pm 9,93$; dan perilaku cyberbullying remaja adalah $22,32 \pm 9,72$. Hasil uji korelasi menunjukkan terdapat hubungan yang negatif signifikan antara komunikasi orang tua-remaja dan kontrol diri remaja dengan perilaku cyberbullying remaja Hasil penelitian ini menunjukkan adanya faktor keluarga dan individu yang berperan dalam menurunkan perilaku cyberbullying pada remaja siswa SMP.
\end{abstract}

Kata kunci: komunikasi orang tua-remaja, kontrol diri, perilaku cyberbullying, remaja

\section{Cyberbullying among Teenager and Its Relationship with Self-Control and Parents- Child Communication}

\begin{abstract}
The increasing of internet using among children and adolescents increases the risk of cyberbullying phenomenon. Therefore, it is needed to conduct a study to further analyze the phenomenon of cyberbullying in Indonesia; especially in order to examine the causal factors so could be useful for develop preventing program. This study aimed to analyze the relationship between teenager's and parent's characteristics, parent-child communication, and self-control; and cyberbullying among teenager who become junior high school students. This research used cross-sectional study design and was conducted in one of junior high school in Bogor city. The 81 students were chosen by convenience sampling for becoming participants. Data were collected by self-administered in measuring teenager's perceive on parent-child communication and also measuring self-control and cyberbullying. The results showed that the mean $\pm S D$ of index (0-100) for parents-child communication was $67,29 \pm 12,32$; teenager's self-control was 58,96 $\pm 9,93$; and teenager's cyberbullying $22,32 \pm 9,72$. Correlation test results showed there was a significant negative relationship between parents-child communication, teenager's self-control and cyberbullying among teenagers. The results of this study indicates the importance of family and individual factors in reducing cyberbullying in junior high school students.
\end{abstract}

Keywords: adolescence, cyberbullying behavior, parent-adolscents communication, self-control

\section{PENDAHULUAN}

Periode remaja rentan dengan berbagai perilaku penyimpangan dan kenakalan, salah satunya adalah perilaku bullying. Berdasarkan data Komisi Perlindungan Anak Indonesia (KPAl) tahun 2014, jumlah kasus bullying di Indonesia menduduki peringkat teratas dari total pengaduan yang dilaporkan oleh masyarakat. Data pada tahun 2014-2016 memperlihatkan terjadi peningkatan pengaduan kasus anak sebagai pelaku bulliying di sekolah dengan 63 kasus pada tahun 2014, 97 kasus pada tahun 2015, dan meningkat menjadi 112 kasus pada tahun 2016. Fakta tersebut menunjukkan besarnya resiko kejadian bullying pada anak, termasuk di dalamnya adalah remaja. Coloroso (2006) menyatakan bahwa bullying dapat terjadi karena adanya kekuatan yang tidak seimbang. Dalam suatu kejadian bullying, terdapat tiga unsur utama yang terlibat, yaitu pelaku atau 
penindas, korban atau tertindas, dan penonton atau orang yang tidak terlibat secara langsung tapi turut menyaksikan kejadian tersebut. Menurut Wang, lannotti, dan Nansel (2009), bullying dapat diklasifikasikan menjadi empat jenis, yaitu bullying verbal, bullying fisik, bullying tidak langsung (relational bullying), dan bullying melalui media internet (cyberbullying). Bahkan disebutkan bahwa cyberbullying adalah intimidasi yang sering terjadi secara daring (Mcvean, 2017).

Cyberbullying merupakan hal baru dari perilaku bullying dengan karakteristik dan akibat yang sama (Narpaduhita \& Suminar, 2014). Menurut Willard (2005), cyberbullying merupakan kegiatan mengirim atau mengunggah materi yang berbahaya atau melakukan agresi sosial dengan menggunakan internet dan teknologi lainnya. Patchin dan Hinduja (2012) menjelaskan cyberbullying terjadi ketika seseorang berulang kali melecehkan, menghina, atau mengejek orang lain menggunakan media internet melalui ponsel atau perangkat elektronik lainnya. Contohnya seperti mengunggah gambar seseorang yang memalukan dan menyebarluaskan melalui media sosial, mengirimkan ancaman melalui pesan singkat berulang-ulang, dan menggunakan akun palsu untuk menghina orang lain.

Penggunaan teknologi internet yang terus meningkat termasuk pada anak dan remaja seperti saat ini maka resiko terjadinya cyberbullying pada anak dan remaja juga semakin besar. Pandie dan Weismann (2016) menyatakan bahwa kecenderungan remaja untuk menjadi pelaku cyberbullying yang pertama yaitu dendam yang tidak terselesaikan. Beberapa cara yang dapat dilakukan oleh pelaku cyberbullying karena dendam yang tidak terselesaikan diantaranya, adalah flamming (amarah) dan harassment (pelecehan). Flamming (amarah) berbentuk ujaran dengan menggunakan pesan elektronik dengan bahasa yang agresif atau kasar. Sementara, harassment (pelecehan) merujuk pada pesan-pesan yang berisi pesan kasar, menghina atau yang tidak diinginkan, berulang kali mengirimkan pesan berbahaya untuk seseorang secara online. Selain karena dendam yang tidak terselesaikan, Pandie dan Weismann (2016) juga menyebutkan bahwa cyberbullying dilakukan karena pelaku yang termotivasi (motivated offonder) untuk melakukan pembajakan, balas dendam, pencurian, atau sekedar iseng. Salah satu bentuk motivated offonder, yakni sekedar iseng dan dalam istilah bullying bentuknya adalah: a) denigration (pencemaran nama baik) yaitu proses mengumbar keburukan seseorang di internet dengan maksud merusak reputasi dan nama baik seseorang tersebut; b) impersonation (peniruan) yaitu dimana seseorang berpura-pura menjadi orang lain dan mengirimkan pesan-pesan atau status yang tidak baik; dan c) trickery (tipu daya) yaitu membujuk seseorang dengan tipu daya supaya mendapatkan rahasia atau foto pribadi orang tersebut. Selanjutnya, selain dendam dan motivasi, cyberbullying juga dapat dilakukan karena keinginan untuk dihormati dan juga karena faktor bosan dan mencari hiburan. Cyberbullying akibat kebosanan dan keisengan untuk mendapatkan kesenangan biasanya dilakukan melalui perencanaan bersama dan dilakukan secara berkelompok. Contoh cyberbullying jenis ini adalah outing, yakni menyampaikan komunikasi pribadi atau gambar yang berisi informasi yang berpotensi memalukan. Alasan lain yang membuat remaja menjadi pelaku cyberbullying menurut Pandie dan Weismann (2016) adalah faktor kesengajaan karena para pelaku mungkin tersakiti atau marah karena komunikasi yang dikirimkan dalam berjejaring sosial. Pelaku cenderung merespon dengan marah atau frustasi.

Di Indonesia, dalam UU No. 11 Tahun 2008 tentang Informasi dan Transaksi Elektronik (ITE) disebutkan bahwa siapa saja yang dengan sengaja dan tanpa hak mendistribusikan informasi elektronik yang melanggar kesusilaan, akan dipidana dengan penjara paling lama 6 tahun dan/atau denda paling banyak satu miliar rupiah. Perangkat hukum ini sebenarnya telah mengakomodir perlindungan dari kekerasan yang dilakukan melalui media sosial. Sartana dan Afriyeni (2017) dalam studinya pada siswa di Padang menemukan bahwa terdapat 78,0 persen siswa yang mengaku pernah melihat cyberbullying, 21,0 persen siswa pernah menjadi pelaku, dan 49,0 persen siswa pernah menjadi korban. Sementara itu, hasil penelitian Safaria (2016) juga menunjukkan bahwa 80 persen siswa (total 102 siswa) dalam penelitiannya telah sering mengalami cyberbullying dan cyberbullying dianggap sebagai peristiwa kehidupan yang penuh stres. Kasus cyberbullying diduga akan terus meningkat seiring dengan kemajuan dalam penggunaan perangkat teknologi informasi. Ada beberapa faktor yang memengaruhi motif perilaku cyberbullying yaitu faktor keluarga, kegagalan dalam mengontrol diri, dan faktor lingkungan (Pandie \& Weismann 2016). 
Kontrol diri adalah kemampuan individu untuk menahan diri atau mengarahkan diri ke arah yang lebih baik ketika dihadapkan dengan godaan-godaan (Hofmann et al., 2012). Apabila remaja memiliki kontrol diri yang baik maka mempunyai peluang lebih besar untuk dapat menghindari perilaku menyimpang seperti halnya cyberbullying. Kontrol diri juga berkaitan dengan cara individu mengendalikan emosi serta dorongan dari dalam dirinya sehingga mampu membuat keputusan dan mengambil tindakan yang efektif sesuai dengan standar ideal, nilai-nilai moral dan harapan sosial (de Ridder et al., 2011). Hasil penelitian Hardani (2017) menemukan bahwa kelekatan orang tua berhubungan positif dengan kontrol diri sehingga menurunkan perilaku menyimpang pada remaja. Bahkan Borba (2001) menyebutkan bahwa kontrol diri termasuk dari dasar kecerdasan moral seseorang yang memberi individu kekuatan untuk berperilaku positif. Remaja yang gagal dalam mengembangkan kontrol diri yang cukup dalam hal tingkah laku berarti gagal dalam mempelajari perilaku yang tidak dapat diterima oleh masyarakat (Aviyah \& Farid, 2014). Kontrol diri menggambarkan keputusan yang diambil individu melalui pertimbangan kognitif untuk menyatukan perilaku yang telah disusun untuk meningkatkan hasil dan tujuan seperti yang diinginkan. Individu dengan kontrol diri yang tinggi sangat memperhatikan cara-cara yang tepat untuk berperilaku dalam situasi yang bervariasi. Kontrol diri dapat dibentuk mulai dari cara berhubungan dengan keluarga (cara berkomunikasi). Hubungan keluarga yang positif mengurangi kemungkinan untuk terlibat dalam perilaku bermasalah yang dilakukan secara online (Noll et al., 2013). Kelekatan anak dengan orang tua dan kontrol diri (self-control) dapat berinteraksi untuk memberikan pengaruh pada perilaku (Boman et al., 2012).

Selain dari faktor kontrol diri, interaksi remaja dengan orang tuanya juga diduga memegang peran penting dalam menekankan perilaku cyberbullying. Salah satunya adalah melalui komunikasi yang positif antara orang tua dengan remaja. Kualitas komunikasi orang tua dan remaja seharusnya dapat berjalan maksimal agar remaja mendapat bimbingan dan pendidikan untuk terhindar dari perilaku cyberbullying. Buruknya kualitas komunikasi orang tua dengan remaja dapat menjadi faktor penyebab penyimpangan perilaku remaja (Gunawan, 2013). Hubungan antara orang tua dan anak dapat menentukan tingkat perkembangan emosi anak mulai dari masa kecil hingga masa remaja (Israel, 2009).
Keluarga yang memfasilitasi remaja untuk mengembangkan kemampuan berkomunikasi yang baik terbukti berhubungan positif dengan perkembangan moralnya. Menurut Diana \& Retnowati (2009), remaja yang memiliki perilaku agresif, suka menyerang dan bertindak kasar, berasal dari keluarga yang sangat minimalis dalam menyediakan ruang komunikasi bagi remaja. Luk et al. (2010) menyebutkan bahwa komunikasi orang tua dan remaja yang kurang optimal akan menyebabkan remaja mudah terpengaruh perilaku menyimpang.

Masa remaja awal menjadi masa peralihan dari masa kanak-kanak ke masa remaja. Masa remaja sering diidentikkan sebagai masa individu mulai berusaha mengenal diri melalui eksplorasi dan penilaian karakteristik psikologis diri sendiri sebagai upaya untuk dapat diterima sebagai bagian dari lingkungan (Steinberg \& Morris, 2001). Sebagian remaja mampu melewati masa peralihanini dengan baik, namun beberapa remaja bisa jadi mengalami kenakalan remaja mulai dari kenakalan ringan hingga kriminal, termasuk di dalamnya kenakalan-kenakalan berbentuk cyberbullying. Penelitian Rahayu (2012) memperlihatkan 32 persen siswa mengatakan pernah melakukan cyberbullying dengan alasan mengisengi temannya dan media yang paling banyak digunakan adalah situs jejaring sosial.

Perilaku cyberbullying dapat berdampak terhadap psikologis korban. Penelitian Rahayu (2012) menemukan 37 persen siswa mengatakan cyberbullying memiliki efek yang lebih banyak terhadap korban. Efek yang dirasakan tidak hanya pada taraf menyakiti perasaan saja namun juga dapat merusak jiwa dan kondisi psikologis dari remaja sehingga menyebabkan korban merasa depresi, sedih, dan frustasi. Salah satu dampak yang dikhawatirkan dari cyberbullying adalah korban cenderung melakukan bunuh diri. Penelitian yang dilakukan Patchin \& Hinduja (2012) mengungkapkan bahwa 20 persen responden dilaporkan pernah berpikir untuk bunuh diri dan semua bentuk bullying secara signifikan berkaitan dengan meningkatnya keinginan untuk bunuh diri. Penelitian ini juga menemukan percobaan bunuh diri yang dicoba dilakukan oleh korban cyberbullying jumlahnya hampir dua kali lebih banyak dari pada remaja yang tidak pernah mengalami cyberbullying. Menurut Aroma \& Suminar (2012), kontrol diri yang rendah mengakibatkan individu senang melakukan risiko dan melanggar aturan tanpa memikirkan jangka panjang. Hal tersebut 
sejalan dengan penelitian Vazsonyi dan Huang (2010) yang menemukan bahwa secara langsung maupun tidak langsung rendahnya pengendalian diri memengaruhi perilaku cyberbullying. Kontrol perilaku yang rendah akan menjadikan individu kesulitan dalam melakukan penyesuaian untuk diterima di lingkungannya.

Selain itu, perilaku agresif remaja yang juga menjadi penciri perilaku cyberbullying, salah satunya juga disebabkan oleh faktor ketidakharmonisan komunikasi dan konflik remaja dengan orang tua (Lascheid 2000 dalam Diana \& Retnowati 2009). Hasil penelitian Diana \& Retnowati (2009) menunjukkan bahwa semakin rendah komunikasi orang tua dengan remaja maka semakin tinggi agresivitas remaja seperti perilaku cyberbullying. Temuan-temuan sebelumnya mengindikasikan bahwa cyberbullying merupakan sebuah fenomena kenakalan yang semakin beresiko terjadi pada remaja karena penggunaan teknologi yang berkembang pesat seperti saat ini. Hasil penelitian sebelumnya telah menemukan dampak negatif dari cyberbullying dan menekankan pentingnya faktor komunikasi antara anak dengan orang tua dan juga faktor kontrol diri dari individu anak dalam mencegah terjadinya cyberbullying. Berdasarkan uraian diatas maka tujuan penelitian ini adalah menganalisis lebih jauh keterkaitan cyberbullying pada remaja dengan dengan komunikasi remaja-orang tua dan juga kontrol diri remaja, khususnya pada remaja yang menjadi siswa SMP.

\section{METODE}

Penelitian ini menggunakan desain cross sectional study di salah satu SMP di Kecamatan Bogor Barat, Kota Bogor. SMP yang dipilih menjadi lokasi penelitian adalah SMP berbasis agama yang juga dikenal sebagai sekolah pesantren modern. Penelitian ini memilih SMP tersebut karena ingin menganalisis lebih lanjut mengenai fenomena cyberbullying pada sekolah dengan sistem pesantren modern yang tentu saja mempunyai sistem pembelajaran yang memadukan antara sistem pesantren (agama) dan juga sistem sekolah formal. Pemilihan lokasi ini diharapkan akan dapat memperkaya kajian mengenai cyberbullying di Indonesia dalam beragam model sistem pembelajaran yang diperoleh remaja.

Remaja awal berusia 12 hingga 15 tahun pada sekolah terpilih berjumlah 425 siswa selanjutnya ditetapkan sebagai populasi dalam penelitian. Teknik pengambilan contoh menggunakan purposive sampling dengan kriteria tertentu. Kriteria tersebut diantaranya adalah siswa di SMP terpilih masih memiliki orang tua lengkap (ayah dan ibu). Pemilihan kriteria tersebut disesuaikan tujuan penelitian adalah menganalisis komunikasi orang tuaremaja. Dari semua populasi terpilih sebanyak 417 siswa yang memenuhi kriteria yaitu memiliki orang tua yang lengkap. Proses pengambilan contoh dalam penelitian dimulai dengan proses screening data sesuai kriteria contoh sebelum pengambilan data dimulai. Selain itu, ketika proses pengambilan data peneliti mengumpulkan siswa yang menyatakan bersedia untuk mengisi kuesioner. Selanjutnya, siswa yang bersedia mengisi kuesioner secara lengkap hanya 81 siswa yang selanjutnya menjadi contoh dalam penelitian ini

Data primer didapatkan melalui wawancara dengan menggunakan alat bantu kuesioner yang meliputi karakteristik remaja (usia, jenis kelamin, uang saku), karakteristik keluarga (usia orang tua, pendidikan orang tua, pendapatan perkapita keluarga, dan besar keluarga), perilaku cyberbullying, komunikasi orang tua-remaja, dan kontrol diri remaja berdasarkan sudut pandang remaja. Data primer diambil dengan cara self-administered terpimpin oleh remaja yang memenuhi syarat penelitian.

Variabel komunikasi orang tua-remaja diukur menggunakan instrumen Parent-Adolescent Communication Scale (PACS) yang dimodifikasi dari Barnes dan Olson (1985) dengan nilai Cronbach's alpha sebesar 0,769. Instrumen ini meliputi dimensi keterbukaan dan permasalahan komunikasi orang tuaremaja yang terdiri dari 17 pernyataan dengan pilihan jawaban menggunakan skala Likert 4 poin (1=Sangat Tidak Sesuai, 2=Tidak Sesuai, 3=Sesuai, dan 4=Sangat Sesuai). Peneliti memodifikasi dengan mengurangi jumlah pernyataan dikarenakan pernyataan tersebut tidak valid, yaitu pertanyaan nomor 5,12 dan 18. Jumlah pernyataan yang asli dalam instrumen Parent-Adolescent Communication Scale (PACS) adalah sebanyak 20 pernyataan.

Sementara itu, kontrol diri diukur menggunakan kuesioner Self Control Scale yang dimodifikasi dari Tangney, Baumeister, dan Boone (2004) dengan nilai Cronbach's alpha sebesar 0,721 . Instrumen kontrol diri memiliki 5 dimensi, yaitu dimensi performa 
kerja, perilaku impulsif, penyesuaian psikologis, hubungan interpersonal, dan emosi moral dengan jumlah pernyataan sebanyak 23 pernyataan. Self Control Scale menggunakan pilihan jawaban skala Likert dari $1=$ "Sangat Tidak Menggambarkan Saya", 2= "Tidak Menggambarkan Saya, 3= "Kadang-Kadang Menggambarkan Saya", 4= "Benar Menggambarkan Saya, hingga $5=$ "Sangat Benar Menggambarkan Saya". Peneliti melakukan modifikasi pada pilihan jawaban untuk memudahkan dan menyesuaikan dengan karakteristik responden. Sementara pilihan jawaban yang asli dalam instrumen Self-Control Scale dibagi menjadi dua tingkatan yang dimulai dari $1=$ "not at all" hingga $5=$ "very much". Selain itu, peneliti mengurangi beberapa item pernyataan yang tidak valid, seperti pada pernyataan nomor 1 , $3,5,7,8,9,10,11,13,16,19,21$ dan 23. Jumlah pernyataan yang asli dalam instrumen Self-Control Scale sebanyak 36 pernyataan.

Selanjutnya, perilaku cyberbullying diukur berdasarkan kuesioner yang dikembangkan oleh peneliti dengan mengacu pada teori Willard (2005) dengan nilai Cronbach's alpha sebesar 0,812. Instrumen terdiri dari 30 pernyataan yang meliputi flaming (pertengkaran online), harassment (berulang kali mengirimkan pesan kasar, denigration (memposting rumor untuk merusak reputasi), impersonation (berpura-pura menjadi orang lain), outing (menyebar rahasia mengenai orang lain), trickery (menghasut), exclusion (sengaja mengeluarkan seseorang dari kelompok online secara kasar) dan cyberstalking (memfitnah). Kuesioner cyberbullying ini menggunakan pilihan jawaban skala Likert 4 poin $(1=$ Selalu, 2=Sering, 3=Hampir tidak pernah, 4=Tidak pernah).

Pengolahan dan analisis data dilakukan dengan menggunakan program Microsoft Excel dan Statistical Package for the Social Sciences (SPSS). Selanjutnya, pada proses pengolahan data, umur orang tua digolongkan menjadi tiga kelompok yaitu dewasa awal ( $\leq$ 40 tahun), dewasa madya (41-60 tahun), dan dewasa akhir (> 60 tahun) (Hurlock, 1980). Besar keluarga dikelompokkan menjadi keluarga kecil ( $\leq 4$ orang), keluarga sedang (57 orang), dan keluarga besar ( $\geq 8$ orang) (BKKBN, 1998). Selain itu, data mentah dari variabel komunikasi orang tua-remaja, kontrol diri dan perilaku cyberbullying dibuat scoring data yang dijumlahkan pada masing-masing variabel tersebut menjadi skor total yang ditransformasikan ke dalam indeks (0-100).
Indeks yang telah didapatkan selanjutnya digunakan untuk mencari rata-rata total dari setiap variabel. Rata-rata yang telah dihitung dari variabel komunikasi orang tua-remaja akan merepresentasikan kategori komunikasi positif dan komunikasi negatif. Komunikasi positif dapat ditunjukkan berdasarkan nilai rata-rata indeks dari dimensi keterbukaan dan komunikasi negatif dilihat berdasarkan ratarata indeks dimensi permasalahan. Komunikasi orang tua-remaja memperlihatkan kategori rendah apabila berada di bawah ratarata indeks skor total komunikasi dan terkategori tinggi apabila berada di atas atau sama dengan rata-rata indeks skor total komunikasi (Toombs, 2014). Variabel kontrol diri dikategorikan berdasarkan nilai rata-rata total indeks. Nilai indeks yang berada pada minimal sama/lebih dari rata-rata total indeks dikategorikan di atas atau sama dengan ratarata. Nilai indeks yang berada dibawah ratarata total indeks dikategorikan di bawah ratarata. Menurut Tangney, Baumeister, dan Boone (2004) semakin tinggi skor yang diperoleh maka semakin tinggi tingkat kontrol diri remaja, begitu pula sebaliknya. Sementara itu, pengategorian variabel perilaku cyberbullying juga ditentukan berdasarkan rata-rata total indeks. Kategori di atas atau sama dengan rata-rata apabila indeks berada minimal sama atau lebih dari rata-rata total indeks. Sementara kategori dibawah rata-rata apabila indeks yang berada dibawah rata-rata indeks. Semakin tinggi juga menunjukkan semakin tinggi pula perilaku cyberbullying yang dilakukan, begitu pula sebaliknya.

Pengolahan dan analisis data menggunakan analisis deskriptif dan analisis korelasi. Analisis deskriptif seperti jumlah, persentase, nilai rataan, standar deviasi, nilai minimum, dan nilai maksimum. Analisis ini digunakan untuk mengidentifikasi karakteristik remaja, karakteristik keluarga, komunikasi masingmasing orang tua dengan remaja, kontrol diri remaja, dan perilaku cyberbullying remaja. Analisis korelasi digunakan untuk memenuhi tujuan dalam menganalisis hubungan karakteristik remaja, karakteristik keluarga, komunikasi orang tua-remaja, dan kontrol diri remaja dengan perilaku cyberbullying pada remaja.

\section{HASIL}

\section{Karakteristik Remaja}

Hasil penelitian menunjukkan lebih dari seperdua remaja $(50,6 \%)$ berjenis kelamin perempuan dan sisanya $(49,4 \%)$ berjenis 
kelamin laki-laki. Remaja pada penelitian ini berada pada rentang 13-14 tahun dengan ratarata usia remaja 14,1 tahun. Rata-rata uang saku remaja sebesar $\mathrm{Rp} 22.728,00$ per hari dengan rentang uang saku sebesar $\mathrm{Rp}$ $5.000,00-\operatorname{Rp} 50.000,00$. Sementara empat dari lima remaja $(80,2 \%)$ memiliki uang saku sebesar Rp 15.000,00 - Rp 30.000,00, sisanya uang saku dibawah Rp 15.000,00 per hari $(9,9 \%)$ dan uang saku di atas $R p$ $30.000,00$ per hari $(9,9 \%)$.

\section{Karakteristik keluarga}

Karakteristik keluarga terdiri atas usia ayah, usia ibu, pendidikan ayah, pendidikan ibu, pendapatan keluarga, dan besar keluarga. Hasil penelitian menunjukkan usia ayah berkisar antara 32-59 dengan rata-rata 46,7 tahun, sementara usia ibu berkisar antara 3156 tahun dengan rata-rata 42,8 tahun. Ratarata usia orang tua remaja dalam penelitian ini termasuk ke dalam kategori dewasa madya. Sementara itu, rata-rata lama pendidikan ayah adalah 14,8 tahun dan rata-rata pendidikan ibu 14,0 tahun. Hasil analisis juga menunjukkan bahwa lebih dari dua pertiga orang tua remaja $(66,7 \%)$ telah menamatkan pendidikan tingkat perguruan tinggi dan masih ditemukan orang tua dengan pendidikan SD $(1,2 \%)$, SMP $(3,7 \%)$, dan SMA $(28,4 \%)$. Pendapatan orang tua remaja berkisar antara Rp1.000.000,00Rp100.000.000,00 per bulan. Rata-rata pendapatan keluarga total mencapai Rp15.675.308,64 per bulan dengan rata-rata pendapatan per kapita per bulan adalah $\mathrm{Rp}$ 3.171.957,00. Hasil analisis data sebaran juga menunjukkan bahwa satu dari dua keluarga terkategori keluarga sedang (5-7 orang), dan sisanya keluarga kecil $0-4$ orang $(39,5 \%)$ dan keluarga besar $(6,2 \%)$.

\section{Komunikasi Orang Tua-Remaja}

Barnes \& Olson (1985) menyatakan bahwa komunikasi orang tua-remaja memiliki dua indikator yang terdiri dari derajat keterbukaan komunikasi dalam keluarga dan kedalaman masalah dalam komunikasi keluarga. Derajat keterbukaan yang tinggi membuat komunikasi orang tua-remaja semakin berkualitas, dan semakin tinggi permasalahan komunikasi semakin rendah kualitas komunikasi. Hasil penelitian menunjukkan rata-rata indeks komunikasi orang tua-remaja sebesar 67,29. Kualitas komunikasi remaja dengan capaian indeks sama dengan/di bawah rata-rata sebanyak 51,90 persen remaja dan sisanya 48,10 persen remaja memiliki kualitas komunikasi di atas rata-rata.
Tabel 1 Nilai minimum, maksimum, rata-rata, dan standar deviasi nilai indeks komunikasi orang tua-remaja per dimensi

\begin{tabular}{lrl}
\hline $\begin{array}{l}\text { Dimensi Komunikasi } \\
\text { Orang tua-remaja }\end{array}$ & Min-Maks & Rata-rata $\pm S D$ \\
\hline Komunikasi (total) & $39,22-96,08$ & $67,29 \pm 12,32$ \\
\hline
\end{tabular}

Hal tersebut ditunjukkan dari sebaran jawaban remaja yang sulit memercayai yang orang tua katakan kepada remaja $(83,9 \%)$, remaja merasa tidak setuju pada pernyataan bahwa orang tua selalu menjadi pendengar yang baik $(93,83 \%)$, remaja merasa orang tua suka membicarakan hal yang tidak seharusnya dibicarakan kepada remaja $(87,65 \%)$, remaja sangat tidak berhati-hati saat sedang berbicara kepada orang tua $(88,89 \%)$, remaja merasa orang tua mengganggu $(97,53 \%)$, dan remaja menyatakan orang tua menghina remaja ketika orang tua remaja marah kepada remaja $(90,12 \%)$. Berdasarkan pernyataan tersebut menyebabkan kualitas komunikasi orang tuaremaja masih harus ditingkatkan.

Meskipun masih banyak aspek komunikasi orang tua-remaja yang perlu ditingkatkan, hasil penelitian juga menemukan adanya kekuatan yang telah ada dalam komunikasi orang tuaremaja. Hal ini terlihat dari sebaran jawaban remaja setuju dengan cara berdiskusi dengan orang tua tanpa rasa malu $(57,0 \%)$, orang tua menjadi pendengar yang baik $(51,0 \%)$, remaja merasa orang tua berusaha untuk memahami cara berfikirnya (62,0\%), remaja mengungkapkan yang dirasakan kepada orang tua $(51,0 \%)$, remaja merasa orang tua dapat memahami perasaannya tanpa harus bertanya $(47,0 \%)$, dan remaja merasa puas dengan cara berkomunikasi dengan orang tuanya $(49,0 \%)$.

\section{Kontrol Diri}

Self-control merupakan kemampuan seseorang untuk menahan suatu respon yang dianggap negatif dan mengarahkannya kepada respon lain yang lebih baik dalam lima faktor yaitu peforma kerja, perilaku impulsif, penyesuian psikologis, hubungan interpersonal dan emosi moral (Tangney Baumeister, \& Boone, 2004). Kontrol diri remaja dalam penelitian ini mempunyai capaian rata-rata indeks adalah 58,96. Rata-rata dimensi yang paling tinggi dibandingkan dengan dimensi yang lain adalah dimensi perilaku impulsif. Hasil penelitian menunjukkan bahwa remaja merasa dapat mengatur diri atau mengatur keinginan yang lebih baik untuk menciptakan kebiasaan hidup yang baik. Sementara, dimensi peforma kerja memiliki rata-rata 51,85 
sehingga remaja merasa kurang menahan gangguan yang menghambat pekerjaan atau tugas (Tabel 2). Remaja juga memperlihatkan kurang memperhatikan jadwal kegiatan.

Hasil menunjukkan hampir setengah remaja $(45,7 \%)$ memiliki kontrol diri diatas atau sama dengan rata-rata dari remaja yang lainnya, sedangkan sisanya 54,3 persen remaja memiliki kontrol diri di bawah rata-rata remaja lainnya. Hal ini disebabkan sebagian remaja merasa santai dan senang apabila ada sesuatu yang menghalangi dalam menyelesiakan tugas $(39,51 \%)$, remaja merasa mengatakan hal yang tidak pantas $(49,39 \%)$, remaja merasa bangun dipagi hari merupakan hal yang sulit dilakukan (41,98\%), dan remaja merasa tidak setuju dengan orang lain yang mengatakan bahwa remaja memiliki kedisiplinan yang tinggi (40,74\%).

\section{Perilaku Cyberbullying}

Willard (2005) beberapa bentuk perilaku yang menjadi ndikator perilaku cyberbullying. Indikator tersebut yaitu: 1) flamming, 2) harassment, 3) denigration, 4) impersonation, 5) outing, 6) exclution, 7) cyberstalking. Penelitian memperlihatkan bahwa rata-rata perilaku cyberbullying pada remaja adalah 22,32 dengan rentang indeks minimal 3,30 dan indeks maksimal adalah 48,90. Exclution menjadi dimensi yang memiliki rata-rata yang lebih tinggi dibandingkan dengan dimensi lainnya dengan nilai rata-rata indeks sebesar 34,97 (Tabel 3). Hasil penelitian ini menunjukkan bahwa remaja merasa suka mengucilkan seseorang dari suatu kelompok secara online. Sementara itu, remaja merasa jarang dalam melakukan perilaku cyberbullying berupa outing dengan rata-rata dimensi terendah sebesar 9,87. Outing merupakan bagian dari perilaku cyberbullying seperti menyebarkan rahasia seseorang, informasi memalukan, atau gambar secara online.

Tabel 2 Nilai minimum, maksimum, rataan dan standar deviasi nilai indeks dari kontrol diri remaja per dimensi

\begin{tabular}{lll}
\hline $\begin{array}{l}\text { Dimensi Kontrol } \\
\text { Diri }\end{array}$ & \multicolumn{1}{c}{ Min-Maks } & $\begin{array}{l}\text { Rata-rata } \pm \\
\text { SD }\end{array}$ \\
\hline Performa kerja & $16,67-100,00$ & $51,85 \pm 14,81$ \\
$\begin{array}{l}\text { Perilaku impulsive } \\
\text { Penyesuaian }\end{array}$ & $20,00-100,00$ & $68,27 \pm 13,92$ \\
psikologis & $0,00-83,33$ & $52,57 \pm 15,96$ \\
$\begin{array}{l}\text { Hubungan } \\
\text { interpersonal }\end{array}$ & $25,00-85,00$ & $54,07 \pm 11,57$ \\
Emosi moral & $32,14-96,43$ & $61,59 \pm 12,47$ \\
Kontrol diri (total) & $38,04-91,30$ & $58,96 \pm 9,93$ \\
\hline
\end{tabular}

Tabel 3 Nilai minimum, maksimum, rata-rata, dan standar deviasi indeks perilaku cyberbullying remaja per dimensi

\begin{tabular}{lcl}
\hline $\begin{array}{l}\text { Dimensi Perilaku } \\
\text { Cyberbullying }\end{array}$ & Min-Maks & Rata-rata \pm SD \\
\hline Flamming & $0,00-66,67$ & $19,34 \pm 16,11$ \\
Harassment & $0,00-60,00$ & $23,45 \pm 14,29$ \\
Denigration & $0,00-58,33$ & $23,04 \pm 13,62$ \\
Impersonation & $0,00-53,33$ & $24,69 \pm 11,63$ \\
Outing & $0,00-66,67$ & $9,87 \pm 14,29$ \\
Trickery & $0,00-55,56$ & $15,63 \pm 14,37$ \\
Exclution & $0,00-88,89$ & $34,97 \pm 17,90$ \\
Cyberstalking & $0,00-66,67$ & $22,90 \pm 17,57$ \\
Perilaku & $3,30-48,90$ & $22,32 \pm 9,72$ \\
cyberbullying & & \\
(total) & & \\
\hline
\end{tabular}

Berdasarkan kategori perilaku cyberbullying menunjukkan hampir satu perdua remaja dalam penelitian ini $(48,3 \%)$ berada pada kategori di bawah rata-rata dari remaja yang lain. Sementara sisanya 42,7 persen adalah remaja yang memiliki kategori perilaku cyberbullying yang dikategorikan di atas ratarata remaja lainnya. Hal ini terlihat dari beberapa perilaku remaja yang suka mengirimkan pesan kepada teman di media sosial dengan tujuan untuk memaksa dan dilakukan lebih dari satu kali $(54,32)$, remaja suka mengejek teman di grup/chatroom $(56,79 \%)$, remaja juga menyatakan tidak akan menasihati apabila ada teman yang mengeluarkan anggota di grup online tanpa sebab $(50,62 \%)$,

\section{Hubungan perilaku cyberbullying remaja dengan komunikasi orang tua-remaja dan kontrol diri remaja}

Tabel 4 yang menyajikan hasil uji hubungan perilaku cyberbullying remaja dengan komunikasi orang tua-remaja dan kontrol diri remaja menunjukkan bahwa adanya keterkaitan antara komunikasi orang tuaremaja secara total $(r=-0,346 ; p<0,01)$ yang berhubungan negatif sangat signifikan dengan perilaku cyberbullying pada remaja. Hal ini berarti diartikan bahwa semakin meningkat dan optimal komunikasi yang dilakukan oleh orang tua ke remaja maka semakin menurun perilaku cyberbullying remaja, dikarenakan remaja dapat terbuka dan orang tua mengetahui konidisi remaja. Sementara itu, kontrol diri pada remaja juga berhubungan negatif signifikan dengan perilaku cyberbullying pada remaja $(r=-0,390 ; p<0,05)$. Hal tersebut juga memperlihatkan bahwa semakin optimal kontrol diri pada remaja maka akan menurun perilaku cyberbullying pada remaja. 
Tabel 4 Nilai koefisien kolerasi Pearson perilaku cyberbullying dengan komunikasi orang tua-remaja dan kontrol diri pada remaja

\begin{tabular}{ll}
\hline \multicolumn{1}{c}{ Variabel } & \begin{tabular}{l} 
Koefisien Korelasi \\
\cline { 2 - 2 }
\end{tabular} \\
\cline { 2 - 2 } & $\begin{array}{l}\text { Perilaku } \\
\text { cyberbullying }\end{array}$ \\
\hline Komunikasi total & $-0,346^{* *}$ \\
Kontrol diri remaja & $-0,390^{* *}$ \\
\hline Keterangan : ${ }^{*}$ nyata pada $p<0,05 ;{ }^{* *}$ nyata pada $p<0,01$
\end{tabular}

\section{PEMBAHASAN}

Tugas dari orang tua adalah mengasuh dan mendidik anak agar tidak menyimpang dari perilaku negatif. Remaja erat kainnya dengan masa mencari identitas diri sehingga memerlukan pendampingan dan dukungan dari orang tua agar terhindar dari perilaku menyimpang. Menurut Puspitawati (2006), tugas utama orangtua adalah mengajarkan cara bersosialisasi pada anaknya dan mengajarkan anaknya tingkah laku sosial yang positif yang diterima oleh lingkungan di sekitarnya. Menurut Puspitawati (2006), adanya gangguan dalam fungsi keluarga khususnya fungsi sosialisasi dan pendidikan mengakibatkan buruknya interaksi antara orangtua dan remaja. Cyberbullying sebagai salah satu perilaku menyimpang yang dapat terjadi dan dilakukan oleh remaja baik sebagai korban ataupun pelaku; juga erat kaitannya dengan faktor penyebab yang berasal dari keluarga.

Hasil penelitian menunjukkan bahwa masih ditemukan dua dari lima remaja yang memiliki kategori perilaku cyberbullying di atas rata-rata remaja lainnya. Penelitian Rahayu (2012) menemukan alasan remaja melakukan cyberbullying dikarenakan iseng saja, dan kejadian ini akan berefek kepada korban yang merasakan. Selain itu, hasil dalam penelitian tersebut juga menyatakan bahwa remaja relatif masih baru mengenal dan belum memahami istilah cyberbullying sehingga sebagian remaja merasa hal itu wajar dilakukan. Perilaku cyberbullying yang paling sering dilakukan oleh remaja dalam penelitian ini adalah mengucilkan seseorang dari kelompoknya secara online, atau yang disebut sebagai exclution. Temuan ini mengindikasikan bahwa dorongan remaja untuk mempertahankan kelompoknya cukup tinggi sehingga secara online akan membuat orang lain yang dinilai tidak sesuai dengan kriteria kelompoknya akan dikucilkan. Selain itu, perilaku impersonation juga sudah dimunculkan oleh para remaja dalam penelitian ini. Dalam perilaku ini, remaja berpura-pura menjadi orang lain dan kemudian memposting atau mengirim materi yang dapat merusak reputasi teman-temannya. Perilaku harassment juga mulai terlihat dalam pemanfaatan teknologi dan media sosial yang dilakukan remaja. Penelitian ini menemukan bahwa remaja juga sudah melakukan perilaku secara online dalam hal mengirim pesan berupa hinaan secara berulang-ulang. Meskipun capaian pada perilaku cyberbullying yang telah dibahas dan disajikan pada Tabel 3 mempunyai indeks yang tidak tinggi, tetap saja perilaku cyberbullying sudah mulai terlihat bentuknya pada remaja dalam penelitian ini.

Sementara itu, kontrol diri remaja pada penelitian ini menunjukkan rata-rata yang lebih rendah dibandingkan dengan kontrol diri yang dimiliki remaja pada umumnya. Hal ini berarti remaja belum dapat mengendalikan diri dan belum dapat mengatur dirinya dengan maksimal sehingga dapat memungkin remaja melakukan hal-hal yang menyimpang. Individu dengan kontrol diri yang rendah cenderung memandang suatu hubungan sebagai permusuhan dan memiliki emosi yang negatif dikarenakan tidak mampu mengontrol hasrat dalam hidup (Burt, Simons, \& Simons, 2006). Adapun hasil penelitian ini akan berkaitan dengan masih tingginya perilaku cyberbullying yang dilakukan oleh remaja. Hasil penelitian juga menyebutkan bahwa remaja tidak menyetujui pendapat orang lain apabila harus memiliki disiplin yang tinggi. Hal ini sejalan dengan penelitian Puspitawati (2006) yang memperlihatkan bahwa remaja di Kota Bogor kurang disiplin dalam masuk sekolah dengan ditunjukkan dari sering terlambat sekolah, sering kesiangan, tidak menggunakan seragam sesuai aturan, dan melanggar tata tertib sekolah. Rendahnya konsep diri dapat menurunkan perkembangan moral remaja juga. Gottfredson dan Hirschi (1990) terbentuknya kontrol diri yang baik dapat ditentukan dari keefektifan dalam mengasuh dan memiliki kelekatan yang kuat antara orang tua dan anak. Pengasuhan dan kelekatan ini salah satunya dapat melalui komunikasi antara orang tua dan anak.

Hasil penelitian komunikasi orang tua dan anak memperlihatkan bahwa setengah dari remaja komunikasinya terkategori rendah, hal ini dikarenakan remaja kurang memiliki hubungan yang baik dengan orang tua, seperti sulit mempercayai orang tua dan kata-kata orang tua dianggap menghina. Komunikasi orang tua dan anak merupakan hal yang penting untuk membangun konsep diri anak sehingga anak dapat mengendalikan diri dari berbagai perilaku menyimpang. Komunikasi remaja yang buruk dengan orang tua menjadi 
prediktor penting dari kenakalan remaja (Cernkovich \& Giordiano, 1987). Selain itu Firdanianty et al. (2016) juga menyebutkan bahwa melalui komunikasi dan interaksi yang positif di dalam keluarga, orang tua dan remaja dapat mempererat hubungan antarpribadi, sehingga remaja tidak mudah terpengaruh oleh ajakan negatif dari teman-temannya. Komunikasi yang intensif antara orang tua dan remaja merupakan faktor pelindung terhadap penggunaan alkohol, tembakau, dan narkoba (Newman, Harrison, \& Dashiff 2008). Ketika orang tua dan anak dapat berkomunikasi terbuka maka anak dapat mempercayai katakata orang tua dan setiap kata orang tua dijadikan sebagai nasihat dan wujud kasih sayang.

Berdasarkan uji korelasi juga menemukan hal yang sama bahwa terdapat hubungan negatif signifikan antara komunikasi orang tua-remaja secara keseluruhan dengan perilaku cyberbullying pada remaja. Hal ini berarti rendahnya komunikasi keterbukaan antara orang tua dengan remaja akan berpotensi untuk meningkatkan perilaku cyberbullying. Ketika orang tua dan remaja tidak saling terbuka maka remaja memiliki peluang melakukan kegiatan yang menyimpang karena tidak ada yang mengendalikan dan memberitahukan perbuatannya sudah benar atau belum. Menurut Diana \& Retnowati (2009), remaja yang memiliki perilaku agresif, suka menyerang dan bertindak kasar, berasal dari keluarga yang sangat minimalis dalam menyediakan ruang komunikasi bagi remaja. Menurut Wang, lannotti, dan Nansel (2009) menyatakan bahwa dukungan orang tua terhadap anak akan menekan atau mencegah terjadi bully maupun victim baik secara fisik, verbal, sosial maupun elektronik. Hasil penelitian Pranadji dan Muharrifah (2010) pengasuhan dengan saling interaksi dan komunikatif dengan ayah akan memberikan kualitas interaksi yang lebih baik. Adapun hasil ini mengindikasikan bahwa penting bagi orang tua untuk mengajak remaja untuk berkomunikasi yang optimal sehingga dapat terhindar dari berbagai perilaku menyimpang dikarenakan orang tua dapat memahami, mengendalikan, dan mengajarkan kepada anak. Selain komunikasi, kontrol diri pada remaja juga berhubungan negatif signifikan dengan perilaku cyberbullying pada remaja. Hal tersebut juga menunjukkan bahwa semakin tinggi kontrol diri pada remaja maka semakin menurunkan perilaku cyberbullying pada remaja. Hal ini sejalan dengan penjelasan Santrock (2007) yang menjelaskan bahwa kontrol diri mempunyai peran penting dalam kenakalan remaja. Kontrol diri yang rendah membuat individu tidak mampu mengatur dan mengarahkan perilakunya. Hal ini sering dialami oleh remaja. Self-control yang tinggi akan berkorelasi dengan kualitas hubungan yang lebih baik, meningkatkan empati serta kesediaan untuk memaafkan kesalahan orang lain (Tangney, Baumeister, \& Boone, 2004). Sementara berdasarkan hasil penelitian Emilia dan Leonardi (2013) menyatakan bahwa kompetensi sosial (sebagai dapat diterima secara sosial, cara berperilaku yang dipelajari yang memampukan seseorang berinteraksi secara efektif dengan orang lain, dan mengarah pada perilaku dan respon-respon sosial yang dimiliki oleh individu) terdapat hubungan negatif signifikan dengan perilaku cyberbullying. Keterbatasan penelitian dikarenakan pemilihan remaja masih menggunakan metode purposive, sehingga belum bisa digeneralisasikan terhadap faktorfaktor yang memengaruhi perilaku cyberbullying pada remaja siswa SMP berbasis agama secara umum. Pengukuran komunikasi orang tua belum membedakan antara komunikasi ayah dengan remaja dan komunikasi ibu dengan remaja sehingga hasil penelitian belum dapat menggambarkan pengaruh komunikasi ayah dan ibu.

\section{SIMPULAN DAN SARAN}

Remaja pada penelitian ini berusia antara 13 sampai dengan 15 tahun, dengan rata-rata usia orang tua remaja termasuk dalam kategori dewasa madya. Lama pendidikan orang tua remaja dengan persentase terbesar adalah tingkat perguruan tinggi. Hasil penelitian menunjukkan capaian komunikasi orang tua-remaja memiliki rata-rata 67,29 dengan persentase yang di atas rata-rata sebesar 48,10 persen dan di bawah rata-rata sebesar 51,90. Capaian kontrol diri remaja memiliki rata-rata 58,96 dengan persentase yang di atas rata-rata sebesar 45,70 persen dan di bawah rata-rata sebesar 54,30. Selanjutnya, capaian perilaku cyberbullying memiliki rata-rata 22,32 dengan persentase yang di atas rata-rata sebesar 42,70 dan di bawah rata-rata sebesar 48,30 . Sementara itu, hasil penelitian juga menunjukkan terdapat hubungan yang negatif signifikan antara komunikasi orang tua-remaja dan kontrol diri remaja terhadap perilaku cyberbullying remaja.

Berdasarkan hasil penelitian menunjukkan bahwa komunikasi orang tua-remaja dan kontrol diri remaja berhubungan negatif dengan perilaku cyberbullying remaja, sehingga diharapkan orang tua dapat lebih 
memperhatikan cara dan intensitas berkomunikasi dengan remaja. Komunikasi dengan anak dan orang tua diharapkan dapat menyalurkan nilai-nilai positif sehingga anak dapat terhindar dari berbagai perilaku menyimpang. Remaja juga diharapkan memiliki kontrol diri yang positif sehingga dapat mengendalikan perilaku negatif. Bagi sekolah diharapkan dapat memberikan pelayanan yang dapat membantu anak mengembangkan sifat-sifat positif anak dapat melalui layanan Bimbingan Konseling sehingga mencegah perilaku negatif. Penelitian selanjutnya diharapkan dapat mengukur komunikasi orang tua-remaja yang dibedakan menjadi komunikasi ayah dengan remaja dan komunikasi ibu dengan remaja, kontrol diri remaja dan perilaku cyberbullying dengan populasi yang lebih besar dan wilayah yang lebih luas. Selain itu, penelitian selanjutnya dapat menambahkan variabel lingkungan sosial seperti lingkungan sekolah, peer group, nilai-nilai agama atau masyarakat sebagai faktor yang memengaruhi perilaku cyberbullying remaja

\section{DAFTAR PUSTAKA}

[BKKBN] Badan Kependudukan dan Keluarga Berencana Nasional. (1998). Buku Pegangan untuk Petugas Lapangan mengenai Reproduksi Sehat. Jakarta: BKKBN

[KPAI] Komisi Perlindungan Anak Indonesia. (2014). Kasus pengaduan anak berdasarkan klaster perlindungan anak. Dapat diakses pada http://www.kpai.go.id/berita/kpai-kasusbullying-dan-pendidikan karakter/\&ei=HjgebuBr\&lc=idID \& $\mathrm{s}=1 \& \mathrm{~m}$ $=771 \&$ host $=$ www.google.co.id\&ts $=1495$ 008925\&sig=AJsQQ1BpCkE3WQtYnQw Cpyp2cx15HZNpPw

Aroma, I.S., \& Suminar, D.R. (2012). Hubungan antara tingkat kontrol diri dengan kecenderungan perilaku kenakalan remaja. Jurnal Psikologi Pendidikan dan Perkembangan, 1(2): 16.

Aviyah, E., \& Farid, M. (2014). Religiulitas, kontrol diri dan kenakalan remaja. Persona, Jurnal Psikologi Indonesia, 3(2):126-129.

Bernes, H.L., \& Olson, D.H. (1985). Parentadolescent communication and the circumplex model. Society for Research in Child Development, 56 (2): 438-447.
Boman, J.H., Krohn, M.D., Gibson, C.L., Stogner, J.M. (2012). Investigating friendship quality: An exploration of selfcontrol and social control theories' friendship hypotheses. Journal of Youth and Adolescence, 41(11), 1526-40, DOI:http://dx.doi.org/10.1007/s10964012-9747-x

Borba, M. (2001). Building Moral Intelligence: The Seven Essential Virtues that Teach Kids to Do the Right Thing. San Francisco (CA): Jossey-Bass.

Burt, C.H., Simons, R., Simons, L. (2006). A longitudinal test of the effects of parenting and the stability of self-control : negative evidence for the general theory of crime. Criminology 44 (2) :353396.

Cernkovich, S.A., \& Giordiano, P.C. (1987). Family relationship and delinquency. Criminology. 24: 295-321.

Coloroso, B. (2006). Penindas, Tertindas, Dan Penonton; Resep Memutus Rantai Kekerasan Anak Dari Prasekolah Hingga SMU. Jakarta: Serambi IImu Pustaka.

de Ridder, D.T., de Boer, B.J., Lugtig, P., Bakker, A.B., \& van Hoof, E.A. (2011). Not doing bad things is not equivalent to doing the right thing: distinguish between inhibitory and initiatory selfcontrol. Personality and Individual Differences. 50 (2011) 1006-1011, DOI: https://doi.org/10.1016/j.paid.2011.01.01 $\underline{5}$

Diana, R.R., \& Retnowati, S. (2009). Komunikasi remaja-orang tua dan agresivitas pelajar. Jurnal Psikologi, 2(2):1-6.

Emilia, \& Leinardi, T. (2013) Hubungan antara kompetensi sosial dengan perilaku cyberbullying yang dilakukan oleh remaja usia 15-17 tahun. Jurnal Psikologi Kepribadian dan Sosial. 2(2):79-89

Firdanianty., Lubis, D. P., Puspitawati, H., Susanto. D. (2016). Pola komunikasi remaja dan pengaruhnya terhadap kecerdasan emosional siswa SMA di Kota Bogor. Jurnal Komunikasi. (1) 3747

Gottfredson, M.R., \& Hirschi, T. (1990). A General Theory of Crime. Standford, CA: Standford University Press 
Gunawan, H. (2013). Jenis pola komunikasi orang tua dengan anak perokok aktif di Desa Jembayan Kecaatan Loa Kulu Kabupaten Kutai Kartanegara. eJournal IImu Komunikasi 1(3):1-5

Hardani, R. (2017). Pengaruh kelekatan anak dengan orangtua, guru, teman dan kontrol diri terhadap perilaku pornografi anak SMP. (Tesis). Institut Pertanian Bogor, Bogor, Indonesia

Hofmann, W., Baumeister, R.F., Förster, G., \& Vohs, K.D. (2012). Everyday temptations: an experience sampling study of desire, conflict, and self-control. Journal of Personality and Social Psychology. 102 (6), 1318-1335, DOI: 10.1037/a0026545

Hurlock, E.B. (1980). Psikologi Perkembangan: Suatu Pendekatan Sepanjang Rentang Kehidupan. Edisi 5. Penerjamah: Istiwidayanti, Doedjarwo. Jakarta: Erlangga

Israel, D. (2009). Staying in School: Arts Education and New York City High School Graduation Rates. New York, NY: Center for Arts Education.

Luk, J.W., Farhat, T., lannotti, R.J., \& Morton, B.G. (2010). Parent-child communication and substance use among adolescents: do father and mother communication play a different role for sons and daughters?. Addictive Behaviors, 35:426-431.

Mcvean, M. (2017). Physical, verbal, relational and cyber-bullying and victimization: examining the social and emotional adjustment of participants (Dissertation). University of South Florida, USA

Narpaduhita, P.D., \& Suminar, D.R. (2014). Perbedaan perilaku cyberbullying ditinjau dari persepsi terhadap iklim sekolah di SMK Negeri 8 Surabaya. Jurnal Psikologi dan Kesehatan Mental, 3(3): 1-6

Newman, K., Harrison, L., \& Dashiff, C. (2008). Relationships between parenting styles and risk behaviors in adolescent health: an integrative literature review. Revista Latino-Americana de Enfermagem. 16: 142-150.

Noll, J.G., Shenk, C.E., Barnes, J.E., \& Haralson, J.A. (2013). Association of maltreatment with high-risk internet behaviors and offline encounters. PEDIATRICS. 131 (2): 510-517, DOI 10.1542/peds.2012-1281
Pandie, M. M., \& Weismann, I, Th. J. (2016). Pengaruh cyberbullying di media sosial terhadap perilaku reaktif sebagai pelaku maupun sebagai korban cyberbullying pada Siswa Kristen SMP Nasional Makassar. Jurnal Jaffray, 14(1): 43-62

Patchin, J. W., \& Hinduja, S. (2012). Cyberbullying Prevention and Respons. New York: Routledge

Pranadji, D.K., \& Muharrifah, A. (2010). Interaksi antara remaja, ayah dan sekolah serta hubungannya dengan tingkat stres dalam menghadapi Ujian Nasional pada siswa SMA. Jurnal IImu Keluarga dan Konsumen, 3 (1): 18-26, DOl: http://dx.doi.org/10.24156/jikk.2010.3.1. 18

Puspitawati, H. (2006). Pengaruh faktor keluarga, lingkungan teman dan sekolah terhadap kenakalan pelajar di Sekolah Lanjutan Tingkat Atas (SLTA) di Kota Bogor. (Disertasi). Institut Pertanian Bogor, Bogor, Indonesia

Rahayu, F.S. (2012). Cyberbullying sebagai dampak negative penggunaan teknologi informasi. Jurnal Sistem Informasi. 8(I). 22-29

Safaria, T. (2016). Prevalence and impact of cyberbullying in a sample of Indonesian junior high school students. The Turkish Online Journal of Educational Technology 15: 1-3.

Santrock, J.W. (2007). Psikologi Perkembangan. Edisi 11 Jilid 1. Jakarta: Erlangga

Sartana, Afriyeni, N. (2017). Perilaku perundungan maya (cyberbullying) pada remaja awal. Jurnal Psikologi Insight Universitas Pendidikan Indonesia,1(1): 25-41

Steinberg, L., Morris, A., S. (2001). Adolescent development. Annual Review of Psychology. 52:83-110.

Tangney, J.P., Baumeister, R.F., \& Boone A.L. (2004). High self-control predicts good adjustment, less pathology, better grades, and interpersonal success. Journal of Personality, 72(2): 271-322.

Toombs, E. (2014). Evaluating the parent adolescent communication toolkit: usability, measure assessment and preliminary content effectiveness (Tesis). Dalhousie University, Kanada, Amerika 
Vazsonyi, A.T. \& Huang, L. (2010). Where selfcontrol comes from: on the development of self-control and its relationship to deviance over time. Developmental Psychology, 46(1), 245-257,DOI: 10.1037/a0016538

Wang, J., lannotti, R.J., \& Nansel, T.R. (2009). School bullying among adolescents in United States: physical, verbal, relational, and cyber. Journal of Adolescent Health. 45 (368-375).
Willard, N. (2005). Cyberbullying and Cyberthreats. Washington: U.S. Departement of Education 